\title{
THE NORMALIZATION OF PUSHBACKS IN GREECE: BIOPOLITICS AND RACIST STATE CRIME
}

\author{
Dimitris Koros
}

\begin{abstract}
The paper discusses pushback operations in Greece as a generalized antiimmigration policy that involves practices constituting racist state crime. Beginning from a description of the illegal operations on the Greek/Turkish borders, this paper examines the constant denial tactics of the government and the response of national, regional and international organizations and institutions. It is shown that pushbacks have become a standardized frontline tool of border management. This phenomenon is approached from a criminological viewpoint in terms of racist state crime and as a racist biopolitical technology of power for the government of the migrant populations, and for the defence of society and national identity. Showing that pushbacks are a becoming a central border policy in Europe, the paper concludes with a discussion of the need for both legal and non-legal counter-strategies.
\end{abstract}

Keywords: pushbacks; Greece; racist state crime; biopolitics; impunity

\section{Introduction}

This paper analyses the phenomenon of pushbacks (and in broader legal terms illegal refoulements) in Greece and discusses the expanding illegal border practices in terms of racist state crime and as a racist biopolitical technology. Starting with an analysis of the current situation in Greece, where illegal refoulements have become a regularized practice, I interrogate the normalization of the phenomenon as a central tool for the government of the migrant populations and flows, the reaction of the international community and national and regional monitoring bodies and the constant denial of the Greek authorities. The discussion continues with an examination of extant approaches towards the conceptualization of these practices as racist state crime, and equally as a racist biopolitical tool for the management of refugees/ migrants as a problem calling for society to be defended. The concluding section considers the expansion of pushback practices, which are not just a phenomenon observed only at the external borders of the EU, but an alarming trend of border impunity, against which legal and non-legal strategies should be employed.

Democritus University of Thrace. 


\section{Illegal Refoulements in Greece}

The practices of illegal refoulements in Greece (mostly at the northern borders in Evros region and the Aegean Islands) have always been one of the main - unofficial tools of the country's migration policy and have been functioning as a frontline choice due to the rise of the refugee flows into the Evros region (Global Legal Action Network 2020), as a consequence of the application of the EU-Turkey Statement of 18 March 2016 (Drakopoulou et al. 2020: 181). ${ }^{1}$ Reports and collection of testimonies from lawyers, NGOs, the United Nations High Commissioner for Refugees (UNHCR), the European Parliament, the Committee for the Prevention of Torture (CPT) and the Council of Europe Commissioner for Human Rights (Council of Europe, Commissioner for Human Rights 2018; United Nations High Commissioner for Refugees 2018; Greek Council for Refugees 2018; Greek Council for Refugees et al. 2018; Human Rights Watch 2018; Greek National Commission for Human Rights 2018; European Parliament 2020a; Council of Europe, Commissioner for Human Rights 2021a) show that pushbacks are a standard practice. Illegal refoulements consist of the unofficial arrest and arbitrary removal of third-country nationals without assessing the legality of their entry or presence in the country and without offering them the possibility to apply for asylum or to object to their removal. According to published testimonies, the actors in these illegal practices are the police, the border guards, the coast guard, the army and in some cases paramilitary groups or persons (Greek Council for Refugees 2018). As for Frontex, ${ }^{2}$ on top of there being few allegations and reports until recently, new evidence shows its direct and/or indirect involvement and this has generated scrutiny from the European Parliament, the EU Ombudsman and OLAF (the European Anti-Fraud Office) (Statewatch 2021).

The removals often do not take place immediately upon the arrival of migrants, or after they have crossed into a part of the territory. Instead, the reports highlight the practice of arbitrary removals of persons who have applied for asylum or even enjoy international protection status in Greece or in another EU country (Greek Council for Refugees 2018). This shows that the operations are rampant, since even legal migrants can be arrested and, despite presenting documents, they may be subjected to this illegal practice (Global Legal Action Network 2020). In cases where the arrest takes place at a distance from the border, migrants are taken to unofficial detention facilities (mainly abandoned police stations or other buildings) and are usually in custody for one night. In other cases, where the arrest takes place during the day and the refoulement is scheduled to take place at night, migrants are detained/warehoused either under the aforementioned conditions or, in some occasions, in police or army vehicles. The detention takes place in degrading conditions, without the provision of food or water. In most cases the detainees 
are not allowed to consume the food or even to use medicine that they might carry (Drakopoulou et al. 2020: 181-2).

The procedure entails the meticulous checking of all personal items and in many occasions verbal or physical abuse. Money is removed, as are other objects such as cell phones and other electronic devices, which are usually thrown in the Evros River or the sea. In other incidents, persons are stripped off their clothes and sometimes even shoes (Mobile Info Team 2019: 5-10). As is shown in the published testimonies of illegal refoulements (Greek Council for Refugees 2018; Greek Council for Refugees et al. 2018; Deeb 2020; Mann and Keady-Tabbal 2020), the danger of being subjected to this illegal, inhuman and degrading practice is omnipresent and concerns any person who either crosses the border, has traversed further in the mainland or even resides in the country possessing or not a legal document: men, women, unaccompanied minors, torture survivors, seriously ill persons, elderly people and pregnant women. The expansion of the practice in the Aegean Sea, posing increased dangers to those victimized under this illegal policy, is even more alarming. The practice is systematic and not occasional (Drakopoulou et al. 2020: 181-2): its repetitiveness shows that it is the preferred tool for the management of the migrant flows, instead of legal procedures. In the 89 incidents of illegal pushbacks, affecting approximately 4,500 persons, recorded by the Border Violence Monitoring Network in the 2020 Annual Torture Report, almost 90\% involved serious mistreatment and torture, while 52\% of the victims were minors. More specifically, $89 \%$ of the incidents included excessive and disproportionate force, $10 \%$ included the use of Electric Discharge Weapons, $44 \%$ involved practices of forced undressing, $15 \%$ involved threats or violence by firearm and $19.7 \%$ inhuman treatment inside police vehicles, while the same treatment was observed regarding incidents where the victims were detained (Border Violence Monitoring Network 2020a).

The practice of pushbacks/illegal refoulements on the Greek/Turkish border involves serious human rights violations and by definition makes the monitoring of the phenomenon practically ineffective, as presence at the border is forbidden (Protecting Rights at Borders 2021: 4). The rights affected and the obligations violated from such practices involve (beyond the principle of nonrefoulement) the right to life, the prohibition of torture and inhuman and degrading treatment, the right to asylum, the right to liberty and security, the right to privacy and the right to family life, the right to an effective legal remedy, the prohibition of discrimination, the duty to rescue at sea (Legal Centre Lesvos 2021: 26-32). Other aspects of the operations entail violations of property rights and issues regarding abuse of power from the actors involved.

Pushbacks are unofficial procedures and the official legal remedies in place cannot prevent the victimization of the refugees (Drakopoulou et al. 2020: 183). 
Even in the cases where an individual addresses their case to justice by filing a lawsuit for the criminal offences against them (torture, robbery, exposition to abuse of power, etc.), the collection of evidence and the substantiation of the claims are almost impossible, since the practice is practically invisible, thus rendering scrutiny fundamentally weak. The forced removal of every electronic device that could be used for the documentation of the offences makes access to justice even more difficult, while serious problems arise since the persons have been returned to Turkey, where substantial protection is lacking and the possibility of chain-refoulement to their country of origin is highly probable (Mobile Info Team 2019: 21-5; Border Violence Monitoring Network 2020b; European Parliament 2020a: 41-2). At that point the main concern of the victims is to plan the next attempt to enter Greece (Drakopoulou et al. 2020: 183).

While the phenomenon of pushbacks has been observed for many years, it was during the 2015-19 Syriza/Anel government that it became routinized and standardized (Greek Council for Refugees 2018). During that period, illegal refoulements in the region of Evros were normalized as an unofficial yet central tool of (anti)migrant deterrent policy. The incidents of pushbacks of refugee boats in the islands of East Aegean were few, while such practices took place for short period in the Pre-removal Detention Center of Paranesti (Northern Greece), where detainees were officially released only to be transferred to Evros River and refouled to Turkey (Greek Council for Refugees 2018). Migrants were arrested and refouled to Turkey even when embarking on intercity buses, while the display of legal documents did not prevent their subjection to such illegal operations (Greek Council for Refugees 2018). Furthermore, even Turkish citizens, members of the opposition, could be refouled and consequently subjected to imprisonment and torture by the country's authorities (Forensic Architecture 2020a).

\section{The Regularization of the Phenomenon and the Constant Denial}

The basic characteristics of the phenomenon of pushbacks/illegal refoulements are: 1) their standardization and not incidental occurrence, 2) their function as a frontline tool for the government of populations and migrant flows, 3) their expansion from Evros to the mainland, the islands of the East Aegean and the detention centres, 4 ) the common use of (sometimes excessive) violence, 5) informal/arbitrary detention, 6) the violation of numerous articles of the Greek Penal Code, 7) the state's constant denial of the existence of the phenomenon and 8) the efforts to downgrade the discourse on illegal refoulements (Drakopoulou et al. 2020: 177-8, 181-2).

The previous government did not recognize the seriousness of the testimonies and silently allowed the phenomenon to rise, refusing any investigation of the crimes or to comment on the reports that were published even in friendly newspapers 
(Protagon 2017). The present government has an even more extreme approach to the migrant/refugee issue and illegal refoulements have become a central tool: during February/March 2020 the antagonisms of the Greek and Turkish borders allowed the police, the army, Frontex and paramilitary vigilantes to push back thousands of refugees (HumanRights360 2020), while stating that they merely deterred the entry of those that the Erdogan regime sent to Greece. The hostile practices towards refugees at the Evros border were publicized and proudly demonstrated to the President of the European Commission (Prime Minister 2020). The government's criticism of President Erdogan's practice on the instrumentalization of desperate refugees functioned merely as a rhetorical scheme for the justification of the extraordinary legal and illegal measures against them (Amnesty International 2020): the suspension of the Geneva Convention for one month, illegal pushbacks, imprisonment for illegal entry with severe penalties under exceptional judicial procedures, cooperation of official state apparatus with armed civilians (HumanRights360 2020); not the kind of treatment considered suitable for people who are presented in the official political discourse and the media as "victims" (Charalambopoulos 2020). The extreme violence unleashed at the time led to the death of at least one person due to fire from the Greek side of the border. (Forensic Architecture 2020b).

Pushback operations on the East Aegean islands, posing extreme dangers for the lives of the victims, have become an inextricable part of the deterrent immigration policy (Deeb 2020). According to Legal Centre Lesvos, the coast guard either destroys the boats of refugees (by destroying the gasoline tanks) when they are arrested at sea, or withholds offers of help for long periods of time when they are arrested on land, leads them to unofficial detention facilities, and then pushes them back through the maritime borders. Violence, inhuman and degrading treatment, and the removal of personal objects, are central characteristics of the practice (Legal Centre Lesvos 2020: 5-7).

The limitation of liberties in spring 2020 during the first measures for the COVID-19 pandemic, a situation operating in near total invisibility, allowed the police to act without any controls: massive arrest operations took place, mostly concerning irregular residents of Diavata refugee camp and other areas of Thessaloniki (Border Violence Monitoring Network 2020c; Human Rights Watch 2020). Thus a practice of kidnapping of refugees - who could not be located by their attorneys, since the police denied having arrested them in the first place - was normalized. The border and the invisibility of Evros were extended to the mainland. In this political climate of national solidarity against refugees, the former Prime Minister, despite the aphoristic negation of the previous period, stated that the actions of the current government against the "geopolitical peril" that refugees constitute are self-evident and that his government also had the same approach but "without making a big fuss out of it" (Star 2020). 
On 10 June 2020, the Minister of Maritime Affairs and Insular Policy stated: "The Coast Guard operates always in conformity with the rules of international law and defends with determination and courage the maritime borders of our country" (Panagoudis 2020a), condemning those who protest pushbacks (therefore including national, regional and international organizations) as "playing Turkey's game" (Panagoudis 2020a), ${ }^{3}$ while the Alternate Minister of Migration and Asylum asserted that "Greece cannot be at the same time a shield and accountable" (AnatropiNews 2020). According to the interim report issued by the Greek Ombudsman, the authorities responded to the complaints of the victims and the civil society organizations by sending "a formal and more or less standardized letter" (2021: 20).

Despite the standard and laconic denial of illegal refoulements from the representatives of the state, the phenomenon has become serious enough to cause a series of institutional reactions: on 10 June the International Organization for Migration (IOM) issued a statement expressing its deep concerns "about persistent reports of pushbacks and collective expulsions of migrants, in some cases violent, at the European Union (EU) border between Greece and Turkey" (2020). IOM states its opposition to a practice which is extremely dangerous for human lives that are already in danger and advises the Greek authorities to "investigate these allegations and testimonies given by people forced to cross the Greece/Turkey border" (IOM 2020). Similarly, on 12 June, the United Nations High Commissioner for Refugees (2020b) invited Greece to investigate the numerous complaints about illegal refoulement operations on the land and sea borders of the country.

On 18 June, the Third Sub-Commission of the Greek National Commission for Human Rights held a hearing of public authorities and civil society organizations on the issue of pushbacks and police violence. The Greek authorities denied the validity of the reports on illegal refoulements, describing them as lies and the product of pressures applied to Greece in order to weaken its border control policy. Despite this unfounded denial, for the Commission (2020), it is evident that there is a progressive consolidation of unofficial refoulements and a steady methodology.

On 6 July, in the meeting of the Committee on Civil Liberties, Justice and Home Affairs of the European Parliament, the members of the Committee invited Greece to investigate the pushback incidents that have been brought to light. The Minister of Citizen Protection and the Alternate Minister on Asylum and Migration denied the existence of such incidents, labelling them as "fake news," refusing the characterization of the current migration policy as "far right" (European Parliament 2020b). The majority demanded from Greece to ensure its compliance to the EU law on asylum and to impose punishment in the cases that the latter is violated (European Parliament 2020b).

Regarding Frontex, despite the criticisms that have been raised on the grounds of its alleged involvement in serious pushback incidents, the Management Board 
of the Agency found no evidence of human rights violations in the cases it reviewed: from the 13 cases examined, eight were found to involve no elements of illegal practices, while five were considered to be in need of further examination (Frontex Management Board Working Group 2021). According to Human Rights Watch, Frontex is "turning a blind eye" to abuses at the Greek/Turkish borders. The documents published regarding the five incidents for which no result was announced raise serious considerations about the complicity of the agency in pushback operations (Cossé 2021).

\section{Illegal Refoulements as State Crime}

According to Green and Ward, the use of threats or physical violence remains a central characteristic of state power in liberal democracies. Therefore, it would be a surprise to meet a state where no criminal or legally ambiguous acts of violence performed by state actors take place (2000: 102), since it is a phenomenon that is observed in all states (Ross 1995: 3). In every state formation there are people with great power, who can resort to actions of serious criminality against citizens or other people subjected to state authority, either as part of the official policy or as a consequence of their mission, the main perpetrators being the police, the army and other actors of security and control (Ross 1995: 15). According to Chambliss (1989), the state can either be the main perpetrator of actions that violate criminal law or act as the primary facilitator of such actions, by contributing to the creation of a state of affairs where crime thrives. Illegal refoulements, though, are not criminal acts per se, but constitute a severe breach of fundamental human rights, and also involve practices that violate criminal law.

The discussion above points to a normalization of illegal refoulements, justifying the claim that they constitute racist state crime (Ward 2015), since actors and institutions that belong to the official state mechanisms and also citizens - who act in a manner that is being tolerated or even encouraged by state actors - perform, assist or/and cover up actions that entail racist violence and directly violate the national and international law on human rights as well as criminal law. Although state crime can victimize any subject or group, the young, the poor and the minorities are more likely to be affected by harmful state actions (Ross 1995: 19), thus rendering race a significant variable that should be further discussed in terms of the racist biopolitical regime of illegal pushbacks. The violence of racist state crime is described as violence that is not dealt overtly and therefore is more secret, invisible and dispersed in time and space. Nixon (2013) uses the term "slow violence," which has been utilized by Ward in order to describe less "spectacular" forms of state violence, stemming from structural violence and systematic disadvantages that are expressed in racial terms. (Ward 2015: 304). However, the racist 
state crime of pushbacks (even when not approached from that perspective) has acquired a very "vivid" visibility, despite the invisibility that the operations themselves entail; this has been the outcome of the monitoring activities and criticism, briefly described above, since incidents of pushbacks are being reported on an daily basis, while interventions from institutional actors against pushbacks are very often in proportion to the severity of the phenomenon. ${ }^{4}$

A model that could be used here is Huggins's analysis (2010) of institutionalized torture in the US as a tool of the "war on terror" policy. She points to ten characteristics of the phenomenon, of which nine are used below to examine illegal refoulements in terms of state crime. ${ }^{5}$ First, illegal practices are defended in terms of the protection of national security and are an inextricable part of the policies for border control and the protection of society's national identity. They thus function as a message addressed to the conservative parts of the society, attempting to set the stage for the justification of unlawful practices, using ideological schemes. (Huggins 2010: 85-6). Second, illegal refoulements are justified in official state discourse not for what they are, but as legal deterrence of entry, aggressive rhetoric for the defence of the practice aiming to eliminate criticism, for which Huggins uses the term "mislabeling" (Huggins 2010: 86), that in essence is an ad hoc legality (third characteristic) (Huggins 2010: 87).

Fourth, in terms of operational organization, we observe that the practice is characterized by bureaucratic organization (Huggins 2010: 89): even on the spot pushbacks require a well-organized patrol, the provision of the necessary vehicles (cars, vans, boats), detailed planning, the concealing of the operation, the obstruction of journalist research (Ross 1995: 13), the efforts of legal aid, etc. The testimonies point in the direction of a well-organized activity which demands many secret and complex communications, techniques of concealment of the practice and of the victims, a chain of actions and communications from the highest to the lowest level (to the extent that one cannot imagine that the regularized practices are simply deviant behaviour by a few state actors, since the negative responses to lawyers attempting to track down their clients come from the high-ranking police officers). Thus, we have a hierarchical division of labour, since there is a distinction between those who plan and those who execute such operations, unless some actors participate in more than one stage, a detail that is not known. Fifth, the operations include multiple actors (Huggins 2010: 91-2): as discussed above, both high- and low-ranking officers of the aforementioned services are involved in illegal refoulements operations, as well as citizens to a small extent.

Sixth, the phenomenon is routinized (Huggins 2010: 94): the more a practice takes place, the more it becomes regularized. Seventh, a central characteristic of the operations is insularity and secrecy (Huggins 2010: 95-6), as everything takes place out of the public eye, by hiding the victims themselves, while the practice is 
systematically concealed from the society, the media, justice and the monitoring mechanisms, constituting a breach of the International Convention for the Protection of All Persons from Enforced Disappearance (Baranowska 2020; Global Legal Action Network 2020). The total invisibility of the victims and the total lack of accountability increase the vulnerability of those persons and the possibility of their victimization.

The eighth characteristic, related to the first three points, is censorship (Huggins 2010: 95-6) and the abnegation of the complaints: proof is either concealed or ignored, the official political discourse uses fake excuses and control procedures are circumvented. The media quickly relay the governmental narrative, and newspapers rarely dedicate reports to illegal operations. Furthermore, the reports and testimonies that substantiate the regularization of the phenomenon are disputed by aggressive discourse, even when the criticism of the phenomenon comes from the most reliable sources such as the UNHCR, IOM, the Greek National Commission for Human Rights and the CPT. ${ }^{6}$ The denial of the existence of regularized fundamental rights abuses that could be recognized as state crime has been termed by Stanley Cohen as states of denial (2001: 7-9), the denial being either literal (nothing happened), interpretative (what happened is something else) or implicatory (what happened is justified). Finally, as discussed above, the impunity (Huggins 2010: 95-6) of certain actions intensifies the invisibility of the system, maintains and regularizes the phenomenon, and increases the possibilities of victimization and intensifies the harm of the victims.

From a similar perspective, the phenomenon of illegal refoulements could be approached as state terrorism, defined as the use of violence against unarmed thirdcountry nationals, aiming to spread fear to an audience which is wider than the direct target of the actual violence exercised (Johnson 2019): illegal refoulements are useful not only for the immediate removal of the migrants as an end per se, but also for the augmentation of fear of those who want to irregularly enter Greece. Especially the fact that even people residing legally in Greece can fall victims of these illegal practices increases terror among the migrant communities.

\section{The Biopolitics of Pushbacks}

The phenomenon of illegal refoulements brings to the forefront a biopolitical aspect of the refugee issue: the management of life in mass terms and in terms of security that includes the possibility of death. From a Foucauldian viewpoint of biopolitics, the issue is not (anymore, or as much as in the past) an expression of sovereign power - without implying, of course, that sovereignty has vanished - but an expression of the right to life or death that is materialized as defence for the survival of society, in terms of completing the sovereign's right "to take life or let live" (Foucault 2003: 240-1), with the power to "make live and let die" (Foucault 2003: 
240-1), "the administration of bodies and the calculated management of life . . a power to foster life or disallow it to the point of death" (Foucault 1990: 165-7); a technology over a population that gives life and allows death, exercised on the population and not the individual, focusing on mass procedures, on phenomena that are approached in collective terms, using tools of predictions, statistical assessments, collective measures and having as objectives the counterbalance of the phenomenon, equilibrium, homeostasis. Put succinctly, the creation of security mechanisms (Foucault 2003: 243-7).

Mbembe's account of modern necropolitics is significant in advancing our understanding of the "politics of enmity" towards those subjected to illegal practices at the borders: as such, the treatment of refugees and migrants could be seen as activating the "fantasy of extermination" or "annihilation" (Mbembe 2019: 43, 64) of those generating a "deep narcissistic wound" (Mbembe 2019: 64), as they are dealt with in existential terms as necessary for the constitution of the subject (citizens of the nation-state) (Mbembe 2019: 48, 54). The security state that emerges rests on the understanding of the Other as a threat to the being itself of the nation, thus pursuing the protection of life and security by resorting to practices of extreme instrumentalization of human life involving the possibility of its destruction (Mbembe 2019: 68, 72).

It is a racist biopower in a society that is exponentially familiarized with death: in March the citizens of Lesvos were cursing the refugees' arriving at the island's shores (To Pontiki 2020). In public discourse, death is now an acceptable possibility of migration policy for the protection of the nation: as journalist Aris Portosalte, a well-known news anchor in Greece, stated: "If your sensibilities tell you that no one should drown, the conversation is over ... Let's not pretend . . . If we don't want anyone to drown then everyone will come to Greece . . . We'll be finished . . I don't really see what deterrence could do ... Are we going to set up fans to blow the boats back?" (Alfavita 2020). The dominant political discourse might be more careful, with a few far-right exceptions, ${ }^{7}$ denying the murderous aspects of the operations, but those materializing them are more enthusiastic about their mission: "we want you to die" (Petridi 2020). ${ }^{8}$ Thus, the border should be seen as a racial regime: according to the Report of the UN Special Rapporteur on contemporary forms of racism, racial discrimination, xenophobia and related intolerance, noncitizens and stateless persons are more vulnerable to being subjected to violence within the context of borders and immigration, "enjoying fewer rights and legal protection" from the increasingly empowered governments (Achiume 2020: 3).

Despite such extreme expressions, death is not the officially declared objective of the border apparatus, as the prism is a perception of life that includes the possibility of death, which is more a consequence of the "revocation of the right to life" than an end in itself (Murray 2006: 198); as in the case of capital punishment, refugees and 
migrants are not killed at the border, their death just "happens" as a "side effect" (Murray 2006: 197-8) of the thanatopolitical border regime. However, this approach does not deal with the loss of lives in terms of simple coincidence, as the death of those who irregularly cross the borders symbolizes the struggle for the survival of the nation, killing and healing are essentially "two sides of the same project" (Esposito 2008: 115), the protection of the social body from an existential threat, by pushing those subjected to illegal border practices "toward a zone of indistinction that isn't completely included in the category of human" (Esposito 2008: 119).

The deterrent migration policy is reinforced with the creation of a floating barrage on the shores of Lesvos and the strengthening of the Evros fence, where the police and Frontex presence is also growing in numbers (E-Evros 2020), which is a further militarization and securitization of the migration policy (To Ethnos 2020; Panagoudis 2020b) and includes the possibility of subjection to dangerous conditions. Until recently getting pushed back was a possibility, but now it has become a normalized technique of government; state crime facilitates the racist biopolitical exposition of the migrant populations to degrading treatment, physical harm, the possibility of death and death itself, as was the outcome of several operations (Callamard 2017; Border Violence Monitoring Network 2020d).

The exposure to the danger of death, the creation of the conditions under which death is an equal possibility with survival and the justification or even the applause of the death of a stranger has a specific utility, justifying the death of the Other as a biological enhancement of the race or the population (Foucault 2003: 258). This function should not be perceived as an act of sovereignty as much as it should be understood as a governmental technique of "distributing the living in the domain of value and utility" (Foucault 1990: 172), a state racism that expresses an imperative for the protection of society against the biological danger that the other, opposite, race poses (Foucault 2003: 255). Racism is characterized by flexibility as a biopolitical mechanism and aims at the purification of the population (by distinguishing between worthy and unworthy life) and as "a governmental technology that juxtaposes and combines various regimes of power" (Rasmussen 2011: 40-1), that is, mechanisms of security, disciplinary techniques and modalities of sovereign power. Therefore, the function of neoracism is "mirrored" in neoliberalism: while the latter is an indirect government of the economy in terms of the population, the former involves the direct targeting of specific sections of it. (Rasmussen 2011: 46-7)

\section{Conclusion: A European Border Impunity?}

On 3 October 2017 Chamber X of the ECtHR issued the famous ND and NT judgment, unanimously condemning Spain for the violation of article 4 of the 4 th Protocol of the Convention, which prohibits collective expulsions, and of article 13 
of the Convention (access to an effective legal remedy), regarding the illegal pushback of two asylum seekers from Sub Saharan countries in Melilla. ${ }^{9}$

The judgment was overturned by a Grand Chamber decision, a development that was described as a "shock" (Pichl and Schmalz 2020). In paragraph 200 of the decision it is stated that "According to the Court's well-established case-law, there is no violation of Article 4 of Protocol No. 4 if the lack of an individual expulsion decision can be attributed to the applicant's own conduct", while, in paragraph 231 the decision continues stating that "it was in fact the applicants who placed themselves in jeopardy by participating in the storming of the Melilla border fences on 13 August 2014, taking advantage of the group's large numbers and using force. They did not make use of the existing legal procedures for gaining lawful entry to Spanish territory."

While an in-depth analysis of the ND and NT Grand Chamber decision beyond the scope of this paper, it is important to assess some aspects of the judgment in light of the normalization of pushbacks as a strategy against migrant flows. According to Poularakis (2020), the Court, in attempting to strike a balance between the right of the state to control its borders and the conditions of entrance and residence of third-country nationals in its territory on the one hand, and the respect for fundamental rights on the other, considers the conduct of those crossing the border as the decisive factor. In an interpretation that limits the scope of the fundamental principle of non-refoulement and of the article 4 of the 4th Protocol of the Convention, it arbitrarily limits the range of the latter by excluding irregular migrants from its scope. The Court blames the victims for the non-use of other legal entry points, instead of focusing on the real inability to access Spanish territory through them and the arbitrary and violent removal of persons who could face danger in case of their expulsion (Moreno 2020).

Therefore, the Grand Chamber Decision expands the range of the individual conduct that can lead to deprivation of protection (despite its reasoning in the very important Saadi v. Italy judgment). ${ }^{10}$ It does so by considering of decisive importance "the conduct of persons who cross a land border in an unauthorized manner, deliberately tak[ing] advantage of their large numbers and us[ing] force ... such as to create a clearly disruptive situation which is difficult to control and endangers public safety" (paragraph 201). However, no evidence was submitted to the Court to prove violent behaviour on the part of the applicants.

Moreover, it leads to an interpretation that accepts the deprivation of fundamental rights without a prior individual assessment, thus rendering the protection from collective expulsions a matter of absolute discretion of the states, since the persons subjected to them do not have the right to be heard and explain their situation (Pichl and Schmalz 2020), and declaring the borders as a zone where fundamental rights do not apply (Moreno 2020). 
The Court not only approved collective expulsions, but it uses the language of legality to justify the deprivation of rights, while it is obvious that it consists of a "retreat" to pressures by the European states, the majority of which have increased the policies of externalization of the immigration control and have normalized the practices of violent pushbacks. Thus, fearing to issue a decision that would be in line with the spirit of the Convention and its own prior rulings, ${ }^{11}$ yet could lead to overwhelming changes to the border control of the EU states, the Court lost in terms of being a reliable defender of human rights in times of crisis (Pichl and Schmalz 2020).

The reasoning of the ND and NT case shows the toleration of practices that entail the submission of third-country nationals to racist violence. According to the recent report by the Protecting Rights at Borders initiative (PRAB 2021), pushbacks are not a phenomenon observed only at the EU external borders: the reports and testimonies collected by ten civil organizations in six countries indicate that governments increasingly resort to illegal border practices that breach fundamental human rights and constitute violations of certain aspects of the criminal legislation, as has been analysed above. Such practices have become a standardized practice of European border agencies: pushbacks have been observed in the borders of France and Italy, Italy and Slovenia, Hungary, Romania and Serbia, Croatia and Bosnia and Herzegovina, North Macedonia, and Greece. The reports state that European countries resort to this de facto tool of border management in a systematic manner, and thus a rights-based approach should be understood as an inherent aspect of relevant practices and procedures (PRAB 2021: 12).

The New Pact on Migration and Asylum of the European Commission also signals a new approach to "crisis" situations: the "Proposal for a Regulation of the European Parliament and of the European Council addressing situations of crisis and force majeure in the field of migration and asylum" (COM/2020/613 final) provides unprecedented powers to the Member States of the EU to derogate from their obligations under EU law, in case they "deem necessary the application of either an asylum crisis management procedure, or a return crisis management procedure, or need to apply derogations from the provisions on registering applications for international protection" (art. 5, para. 3). Pushbacks per se, of course, are not legalized by the Pact, but an infringement of the European asylum acquis and a de jure suspension of fundamental procedures and rules could legitimize illegal border practices, since the Commission regards the "political crisis" at the Greek/ Turkish border in February/March 2020 as "force majeure" that could lead to dangerous practices (Refugee Support Aegean 2020: 3).

What is evident from the above is that we are dealing with a Greek and European policy for the deterrence of migration "at any cost" (Legal Centre Lesvos 2021: 43), a biopolitical pushback regime using racist state crime as the means to do this. This 
regime is characterized by impunity, despite the rising global attention to the matter. Therefore, the inhuman and degrading violent border practices could and should be addressed with all legal means available (judicial and non-judicial), among which could be the employment of criminal law (Mann forthcoming: 2, 18-19). However, despite the possibilities that legal strategies offer, judgments such as the ND and NT v. Spain make clear that we should deal with illegal refoulements not only by the limiting scope that positive law offers. This of course shall not imply that law is of minor importance as a strategic codification of power relations and as a field for intervention, but that pushbacks ought to be approached as a racist biopolitical technology of power that, on the one hand, lead to the violation of fundamental rights, that are stripped of their content, and on the other to a familiarization of the state apparatus and of the society as a whole with illegal, inhuman and excessive violence as a defence from people who, instead of being protected, are subjected to conditions that render the eventuality of death and death itself as acceptable consequences of a policy for the protection of national identity. Thus, it is of extreme importance that strategies against pushbacks also aim at "safe and legal routes to Europe, as well as defunding, demilitarizing and dismantling Europe's violent border regime” (Legal Centre Lesvos 2021: 43).

\section{Acknowledgements}

The author would like to thank the two anonymous reviewers for their careful reading of the manuscript and their many insightful comments and suggestions. I would also like to thank Georgios Papanicolaou, Associate Professor, Northumbria Law School (Northumbria University, Newcastle, United Kingdom) for his comments and suggestions, and Sofia Tzelepi for her generous help.

\section{Notes}

1. From 3,784 land arrivals in 2016, to 6,592 in 2017, 18,014 in 2018 and 14,887 in 2019. (United Nations High Commissioner for Refugees 2020a).

2. Regarding Frontex, the paper discusses the illegal practices at the Greek/Turkish borders in terms of state crime. The activities of Frontex stem from the country's membership in the EU. Although Frontex's involvement in the illegal operations could be dealt with as violation of human rights obligations and criminal law legislation, the term "state crime" cannot apply to the activities of the agency. We could argue that Frontex is an accomplice in state crime but not a perpetrator per se.

3. The most cynical admission is from the alt-right government MP Bogdanos: "We thank the comrades for advertising the government's policies. Yes, boats are now returned-and will be returned-back to Turkey; the order to the Coast Guard is clear, the country has ceased being a lustful for Islam, neo-leftist, illegal-migrant-Disneyland" (Efimerida ton Sintakton 2020).

4. See the Commissioner for Human Rights of the Council of Europe (2021) intervention of the Greek government on the issue.

5. Competition between government agencies and government agents, the sixth characteristic that the author employs (Huggins 2010: 93), was considered not to fit in the comparison. Therefore, the enumeration from there on changes in our adoption of her analysis. 
6. In its most recent report on the visit of March 2020 it calls on the country once again to end pushbacks (European Committee for the Prevention of Torture and Inhuman and Degrading Treatment 2020).

7. The then non-member of Nea Dimokratia, and now governmental MP, Plevris has a different opinion: "securing the borders cannot exist if there are no casualties and, to be more clear, if there are no dead!" (Left.gr. 2014).

8. An interesting aspect regarding this would be the impact of far-right ideas and practices in the ranks of the Greek police: as is shown by Papanicolaou and Papageorgiou (2016), the electoral support of the neo-Nazi party Golden Dawn was alarming among the ranks of the Greek police officers' special electoral rolls.

9. ND and NT v. Spain [GC], nos. 8675/15 and 8697/15, 13 February 2020.

10. Saadi v. Italy [GC], no. 37201/06 EctHR, 28 February 2008.

11. With Hirsi Jamaa and Others v. Italy [GC], no. 27765/09, ECtHR 23 February 2012, Sharifi and Others v. Italy and Greece no. 16643/09, ECtHR, 21 October 2014 and other related judgments.

\section{References}

Achiume, T. (2020) Report of the Special Rapporteur on contemporary forms of racism, racial discrimination, xenophobia and related intolerance (A/75/590). Available online at: https://www. ohchr.org/en/issues/racism/srracism/pages/indexsrracism.aspx (accessed 25 May 2021).

Alfavita (2020) "Vile Statements from Portosalte: 'If we Want Nobody to Get Drowned Everybody Will Come to Greece", 17 January. Available online at: https://www.alfavita.gr/kosmos/309627 athliotites-portosalte-gia-toys-prosfyges-den-theloyme-na-pnigei-kaneis-tha-erhontai (in Greek) (accessed 25 May 2021).

Amnesty International (2020) Trapped in Political Games. Refugees in the Greek-Turkish Border Pay the Price for Europe's Failure. Available online at: https://www.amnesty.gr/sites/default/files/ ekthesi_egklovismenoi_es_se_politika_paihnidia.pdf (accessed 25 May 2021).

AnatropiNews (2020) "UNHCR Calls Greece on Pushbacks - Koumoutsakos: Greece cannot be a Shield and Accountable", 13 June. Available online at: https://www.anatropinews.gr/2020/06/13/ ypati-armosteia-kalei-ellada-tis/ (accessed 25 May 2021).

Baranowska, G. (2020) "Disappeared Migrants and Refugees." German Institute for Human Rights. Available online at: https://www.institut-fuer-menschenrechte.de/fileadmin/Redaktion/Publikationen/ Analyse_Studie/Analysis_Disappeared_Migrans_and_Refugees.pdf (accessed 25 May 2021).

Border Violence Monitoring Network (2020a) Annual Torture Report. Available online at: https://www.borderviolence.eu/wp-content/uploads/Annual-Torture-Report-2020-BVMN.pdf (accessed 25 May 2021).

Border Violence Monitoring Network (2020b) Pushback from Lagadikia Camp. Available online at: https://www.borderviolence.eu/violence-reports/september-16-2020-0000-lagadikia-greece/ (accessed 25 May 2021).

Border Violence Monitoring Network (2020c) "Press Release: Documented Pushbacks from Centers on the Greek Mainland." Available online at: https://www.borderviolence.eu/press-release-documented-pushbacks-from-centres-on-the-greek-mainland/ (accessed 25 May 2021).

Border Violence Monitoring Network (2020d) "I Saw People Walk into the River and the Current Took them Away." Available online at: https://www.borderviolence.eu/violence-reports/october30-2020-0000-nea-vyssa/ (accessed 25 May 2021).

Callamard, A. (2017) Unlawful Death of Refugees and Migrants. Report of the Special Rapporteur of the Human Rights Council on Extrajudicial, Summary or Arbitrary Executions (A/72/335). Available online at: https://www.refworld.org/docid/59b923524.html (accessed 25 May 2021). 
Chambliss, W. (1989) "State Organized Crime: The American Society of Criminology 1988 Presidential Address", Criminology, Vol. 34: 183-208.

Charalambopoulos, L. (2020) "Erdogan is a Cynical Sultan, But Refugees are Human Beings", Ta Nea, 1 March. Available online at: https://www.tanea.gr/2020/03/01/opinions/o-erntogan-einaienas-kynikos-soultanos-omos-oi-prosfyges-einai-anthropoi/ (in Greek) (accessed 25 May 2021).

Cohen, S. (2001) States of Denial: Knowing about Atrocities and Suffering. London: Polity Press.

Cossé, E. (2021) "Frontex Turns a Blind Eye to Greece's Border Abuses." Human Rights Watch. Available online at: https://www.hrw.org/news/2021/03/10/frontex-turns-blind-eye-greeces-border-abuses (accessed 25 May 2021).

Council of Europe, Commissioner for Human Rights (2018) Report of the Commissioner for Human Rights of the Council of Europe Dunja Mijatović Following her Visit to Greece from 25 to 29 June 2018. Available online at: https://rm.coe.int/report-on-the-visit-to-greece-from-25-to-29-june2018-by-dunja-mijatov/16808ea5bd (accessed 25 May 2021).

Council of Europe, Commissioner for Human Rights (2021a) A Distress Call for Human Rights: The Widening Gap in Migrant Protection in the Mediterranean. Available online at: https://rm.coe.int/a-distress-callfor-human-rights-the-widening-gap-in-migrant-protectio/1680a1abcd\#: :text=In\%202019\%2C\%20 according\%20to\%20IOM,than\%20the \%20whole\%20of\%202019 (accessed 25 May 2021).

Council of Europe, Commissioner for Human Rights (2021b) "Letter to Minister for Citizen's Protection, the Minister of Migration and Asylum and the Minister of Shipping and Island Policy of Greece." Available online at: https://rm.coe.int/letter-to-mr-michalis-chrysochoidis-ministerfor-citizens-protection-o/1680a256ad (accessed 25 May 2021).

Deeb B. (2020) "Samos and the Anatomy of a Maritime Push-back", Bellingcat. Available online at: https://www.bellingcat.com/news/uk-and-europe/2020/05/20/samos-and-the-anatomy-of-a-maritime-push-back/ (accessed 25 May 2021).

Drakopoulou, A., Konstantinou, A. and Koros, D. (2020) "Border Management at the External Schengen Borders: Border Controls, Return Operations and Access to Effective (?) Remedies in Greece", in S. Carrera. and M. Stefan, eds., Fundamental Rights Challenges in Border Controls and Expulsion of Irregular Immigrants in the European Union: Complaint Mechanisms and Access to Justice. New York: Routledge Publishing.

Efimerida ton Sintakton (2020) "Psychogios' Rage for Bogdanos' 'Inhuman Post”, 11 May. Available online at: https://www.efsyn.gr/politiki/antipoliteysi/242835_orgi-apo-psyhogio-gia-tin-apanthropianartisi-mpogdanoy (accessed 25 May 2021).

E-Evros (2020) "Frontex Remains in Evros - the Executive Director of Frontex Talks about the Border Operation", 8 June. Available online at: https://www.e-evros.gr/gr/eidhseis/3/parameneih-frontex-ston-ebro-o-ektelestikos-diey8ynths-ths-frontex-mila-gia-thn-epixeirhsh-sta-synora/ post40454 (accessed 25 May 2021).

Esposito, R. (2008) Bios: Biopolitics and Philosophy. Minneapolis and London: University of Minnesota Press.

European Committee for the Prevention of Torture and Inhuman and Degrading Treatment (2020) Report to the Greek Government on the Visit to Greece Carried out by the European Committee for the Prevention of Torture and Inhuman or Degrading Treatment or Punishment (CPT) from 13 to 17 March 2020. Strasbourg: Council of Europe.

European Parliament (2020a) EU External Migration Policy and the Protection of Human Rights. Available online at: https://www.europarl.europa.eu/RegData/etudes/IDAN/2020/603512/EXPO_ IDA(2020)603512_EN.pdf (accessed 25 May 2021).

European Parliament (2020b) "Investigate Alleged Pushbacks of Asylum-Seekers at the GreekTurkish Border, MEPs Demand.” Available online at: https://www.europarl.europa.eu/news/en/ 
press-room/20200703IPR82627/investigate-pushbacks-of-asylum-seekers-at-the-greek-turkishborder-meps-demand (accessed 25 May 2021).

Forensic Architecture (2020a) "Pushbacks across the Evros/ Meriç River: The Case of Ayşe Erdoğan." Available online at: https://forensic-architecture.org/investigation/pushbacks-across-the-evrosmeric-river-the-case-of-ayse-erdogan (accessed 25 May 2021).

Forensic Architecture (2020b) "The Killing of Muhammad Gulzar." Available online at: https://forensic-architecture.org/investigation/the-killing-of-muhammad-gulzar (accessed 25 May 2021).

Foucault, M. (1990) History of Sexuality, vol. 1. An Introduction. New York: Pantheon Books.

Foucault, M. (2003) Society Must Be Defended: Lectures at the Collège de France 1975-1976. New York: Picador.

Frontex Management Board Working Group (2021) Fundamental Rights and Legal Operational Aspects of Operations in the Aegean Sea. Final Report of the Frontex Management Board Working Group. Available online at: https://frontex.europa.eu/assets/Key_Documents/MB_Documents/ Agenda_Point_WG_FRaLO_final_report.pdf (accessed 25 May 2021).

Global Legal Action Network (2020) Enforced Disappearance and Expulsion at Greece's Evros Border. Available online at: https://www.glanlaw.org/enforced-disappearance-greece (accessed 25 May 2021).

Greek Council for Refugees (2018) Reports and Testimonies of Systematic Pushbacks in the Evros Region. Available online at: https://www.gcr.gr/media/k2/attachments/ReportZ08032018.pdf (accessed 25 May 2021).

Greek Council for Refugees, ARSIS and HumanRights360 (2018) “The New Normality: Continuous Push-backs of Third Country Nationals on the Evros River." Available online at: https://www.gcr. $\mathrm{gr} / \mathrm{en} /$ news/press-releases-announcements/item/1028-the-new-normality-continuous-push-backsof-third-country-nationals-on-the-evros-river (accessed 25 May 2021).

Greek National Commission for Human Rights (2018) “GNCHR Statement on Complaints Regarding Informal Push-backs at the Evros Region." Available online at: http://www.nchr.gr/images/ English_Site/PROSFYGES/GNCHR_Statement_Informal\%20push-backs_in_\%20Evros_2018. pdf (accessed 25 May 2021).

Greek National Commission for Human Rights (2020) "Announcement Regarding Reported Pushback Practices.” Available online at: http://www.nchr.gr/images/pdf/apofaseis/prosfuges_metanastes/Dilosi\%20 EEDA_Anaferomenes\%20praktikes\%20epanaproothiseon.pdf (in Greek) (accessed 25 May 2021).

Greek Ombudsman (2021) Alleged Pushbacks to Turkey of Foreign Nationals that have Arrived in Greece Seeking International Protection. Available online at: https://www.synigoros.gr/resources/ docs/280421-pushbacks-interim-report-eng.pdf (accessed 25 May 2021).

Green, P. and Ward, T. (2000) "State Crime, Human Rights and the Limits of Criminology", Social Justice, 27(1): 101-15.

Huggins, M.K. (2010) "Modern Institutional Torture as State-Organized Crime”, in W.J. Chambliss, R. Michalowski and C.K. Kramer, eds, State Crime in a Global Age. Cullompton: Willan Publishing, 83-102.

Human Rights Watch (2018) “Greece: Violent Pushbacks at Turkey Border.” Available online at: https:// www.hrw.org/news/2018/12/18/greece-violent-pushbacks-turkey-border (accessed 25 May 2021).

Human Rights Watch (2020) "Greece: Investigate Pushbacks, Collective Expulsions." Available online at: https://www.hrw.org/news/2020/07/16/greece-investigate-pushbacks-collective-expuls ions?fbclid=IwAR1 KFOXZq9kDfpyMrlx0C39Kx2bBSex1GBqVsnBkRp_9HTo57B4JyKk5cwA (accessed 25 May 2021).

HumanRights360 (2020) During and After Crisis: Evros Border Monitoring Report (November 2019April 2020). Available online at: https://www.humanrights360.org/el/mesa-kai-meta-tin-krisiepopteia-sta-chersaia-synora-toy-evroy/ (accessed 25 May 2021). 
International Organisation for Migration (2020) "IOM Alarmed over Reports of Pushbacks from Greece at EU Border with Turkey." Available online at: https:/greece.iom.int/en/news/iomalarmed-over-reports-pushbacks-greece-eu-border-turkey (accessed 25 May 2021).

Johnson, P.L. (2019) "The Crime and State Terrorism Nexus: How Organized Crime Appropriates Counterinsurgency Violence", Perspectives on Terrorism, 13(6): 16-26.

Left.gr. (2014) "When Plevris Demanded Dead Migrants at the Borders", 23 January. Available online at: https://left.gr/news/otan-o-pleyris-zitoyse-nekroys-metanastes-sta-synora-vinteo (accessed 25 May 2021).

Legal Centre Lesvos (2020) Collective Expulsions Documented in the Aegean Sea: March-June 2020. Available online at: http://legalcentrelesvos.org/wp-content/uploads/2020/07/CollectiveExpulsions-in-the-Aegean-July-2020-LCL.pdf (accessed 25 May 2021).

Legal Centre Lesvos (2021) Crimes Against Humanity in Greece. Available online at: http://legalcentrelesvos.org/wp-content/uploads/2021/02/Collective-Expulsions-in-the-Aegean-LCL-01.02.2021-1. pdf (accessed 25 May 2021).

Mann, I. and Keady-Tabbal, N. (2020) "Torture by Rescue: Asylum-Seeker Pushbacks in the Aegean. How Summary Expulsions from Greece have Continued with Impunity", Just Security. Available online at: https://www.justsecurity.org/72955/torture-by-rescue-asylum-seeker-pushbacks-in-theaegean/ (accessed 25 May 2021).

Mann, I. (forthcoming) "The New Impunity: Border Violence as Crime”, University of Pennsylvania Journal Law, Vol. 42: 1-49.

Mbembe, A. (2019) Necropolitics. Durham, NC, and London: Duke University Press.

Mobile Info Team (2019) Illegal Pushbacks in Evros: Evidence of Human Rights Violations at the Greece/Turkey Border. Available online at: https://www.statewatch.org/media/documents/ news/2019/dec/gr-tu-mobile-info-team-pushbacks-report-11-19.pdf (accessed 25 May 2021).

Moreno C.O. (2020) "A Painful Slap from the ECtHR and an Urgent Opportunity for Spain", Verfassungsblog. Available online at: https://verfassungsblog.de/a-painful-slap-from-the-ecthrand-an-urgent-opportunity-for-spain/ (accessed 25 May 2021).

Murray, S.J. (2006) "Thanatopolitics: On the Use of Death for Mobilizing Political Life", Polygraph: An International Journal of Politics and Culture, Vol. 18: 191-215.

Nixon, R. (2013) Slow Violence and the Environmentalism of the Poor. Cambridge, MA: Harvard University Press.

Panagoudis, G. (2020a) "Plakiotakis Confesses Pushbacks", Efimerida ton Sintakton, 11 June. Available online at: https://www.efsyn.gr/ellada/koinonia/247254_omologia-plakiotaki-gia-tisepanaproothiseis (in Greek) (accessed 25 May 2021).

Panagoudis, G. (2020b) “The Floating Barrage will be Put into Action”, Efimerida ton Sintakton, 25 June. Available online at: https://www.efsyn.gr/ellada/koinonia/249270_energopoieitai-plotofragma (in Greek) (accessed 25 May 2021).

Papanicolaou, G. and Papageorgiou, I. (2016) "The Police and the Far Right in Greece: A Case Study of Police Voting Behaviour in Athens", Crime, Law and Social Change, 66(4): 397-419.

Petridi, K. (2020) “'We Want you to Die' - Allegations for Pushbacks Increase”, Vice, 30 July. Available online at: https://www.vice.com/gr/article/n7wqzm/hr8an-maskoforoi-kai-masphran-th-mhxanh-oi-kataggelies-gia-epanaprow8hseis-sto-aigaio-plh8ainoyn?fbclid=IwAR 2cNVmMZOepyZeBi1XtZ65dvNfiWzatru13v6fBR0m1vUYe9AyWZq6jZIA (accessed 25 May 2021).

Pichl, M. and Schmalz, D. (2020) “'Unlawful' may Not Mean Rightless: The Shocking ECtHR Grand Chamber Judgment in Case N.D. and N.T", Verfassungsblog. Available online at: https://verfassungsblog.de/unlawful-may-not-mean-rightless/ (accessed 25 May 2021). 
Poularakis, S. (2020) "Refugees, Immigrants and State Sovereignty: The Decision of the Strasbourg Court for the Melilla Fence", Syntagmawatch.gr. Available online at: https://www.syntagmawatch. gr/trending-issues/prosfyges-metanastes-kai-kratiki-kyriarchia-i-apofasi-tou-dikastiriou-tou-strasvourgou-gia-ton-fraxti-tis-ispanias-sti-meligia/ (accessed 25 May 2021).

Prime Minister of Greece (2020) "Statements by Prime Minister Kyriakos Mitsotakis in Kastanies, Evros, Following his Visit with the Heads of the EU Institutions at the Greek-Turkish Border", 3 March. Available online at: https://primeminister.gr/en/2020/03/03/23458 (accessed 25 May 2021).

Protagon (2017) "Wordplay by the Government Regarding Pushbacks of Turkish Citizens", 8 June. Available online at: https://www.protagon.gr/epikairotita/44341424217-44341424217 (accessed 25 May 2021).

Protecting Rights at Borders (2021) "Pushing Back Responsibility. Rights Violations as a 'Welcome Treatment' at Europe's Borders.” Available online at: https://www.gcr.gr/en/ekdoseis-media/reports/ reports/item/1708-prab-report-regarding-pushbacks-at-europe-s-borders-january-may-2021 (accessed 25 May 2021).

Rasmussen, K.S. (2011) "Foucault's Genealogy of Racism", Theory, Culture and Society, 28(5): $34-51$.

Refugee Support Aegean (2020) RSA Comments on the Commission Proposal for a Regulation Addressing Situations of Crisis and Force Majeure in the Field of Migration and Asylum $\operatorname{COM}(2020)$ 613. Available online at: https://rsaegean.org/wp-content/uploads/2020/10/RSA_ Comments_Crisis.pdf (accessed 25 May 2021).

Ross, J.I. (1995) "Controlling State Crime: Toward an Integrated Structural Model”, in J.I. Ross, ed., Controlling State Crime. New York: Garland Publishing.

Star (2020) "Tsipras: Any Government would Close the Borders", 3 March. Available online at: https:// www.star.gr/eidiseis/politiki/492007/tsipras-kai-emeis-kleisame-ta-synora (in Greek) (accessed 25 May 2021).

Statewatch (2021) "Frontex Investigations: What Changes in the EU Border Agency's Accountability?" Available online at: https://www.statewatch.org/analyses/2021/frontex-investigations-whatchanges-in-the-eu-border-agency-s-accountability/ (accessed 25 May 2021).

To Ethnos (2020) "Strong Message by Chrisochoidis: The Guardians of Evros are Here - the Fence will be Materialised", 27 May. Available online at: https://www.ethnos.gr/politiki/107723_ihirominyma-hrysohoidi-oi-fylakes-toy-ebroy-einai-edo-o-frahtis-tha-ginei (accessed 25 May 2021).

To Pontiki (2020) "Lesvos: "You shouldn’t have been F@@ked like a Bitch and Get Pregnant" Shameful Situations in Thermi Port", 1 March. Available online at: http://www.topontiki.gr/article/370876/lesvos-na-mi-giosn-sa-ti-skyla-na-min-isoyna-gkastromeni-mori-eikones-ntropis-sto (in Greek) (accessed 25 May 2021).

United Nations High Commissioner for Refugees (2018) "Desperate Journeys: Refugees and Migrants Arriving in Europe and at Europe's Borders." Available online at: https://www.unhcr.org/desperatejourneys/ (accessed 25 May 2021).

United Nations High Commissioner for Refugees (2020a) Operational Portal. Available online at: https://data2.unhcr.org/en/situations/mediterranean/location/5179 (accessed 25 May 2021).

United Nations High Commission for Refugees (2020b) "UNHCR Calls on Greece to Investigate Pushbacks at Sea and Land Borders with Turkey.” Available online at: https://www.unhcr.org/ news/briefing/2020/6/5ee33a6f4/unhcr-calls-greece-investigate-pushbacks-sea-land-borders-turkey.html (accessed 25 May 2021).

Ward, G. (2015) “The Slow Violence of State Organized Race Crime”, Theoretical Criminology, 19(3): 299-314. 